\title{
MODELING OF BASIC DENSITY OF WOOD FROM Eucalyptus grandis AND Eucalyptus urophylla USING NONDESTRUCTIVE METHODS
}

\author{
Allan Motta Couto', Paulo Fernando Trugilho², Thiago Andrade Neves ${ }^{3}$, \\ Thiago de Paula Protásio ${ }^{4}$, Vânia Aparecida de Sá1
}

(received: April 11, 2011; accepted: September 28, 2012)

\begin{abstract}
The objective of this study was to evaluate the accuracy of nondestructive variables in inferring basic density of wood from Eucalyptus grandis and Eucalyptus urophylla. A total of 27 clones of Eucalyptus urophylla and 22 clones of Eucalyptus grandis were used, sourced from a clonal trial set up in Martinho Campos, Minas Gerais. After evaluation using nondestructive techniques of resistography and pin penetration at a constant pressure (Pilodyn $\left.{ }^{\circledR}\right)$, individuals were felled and disks were removed from the $2 \%, 10 \%, 30 \%, 50 \%$ and $70 \%$ portions of the merchantable height section, and also from the portion $1.30 \mathrm{~m}$ above ground level. Basic density was determined by the water immersion method. Values of basic density ranged from 0.412 to $0.609 \mathrm{~g} . \mathrm{cm}^{-3}$ for clones at age 42 months and from 0.408 to $0.664 \mathrm{~g} . \mathrm{cm}^{-3}$ for clones at age 54 months. The clones of Eucalyptus urophylla provided higher values of average basic density in relation to Eucalyptus grandis. The variable 'amplitude' had better correlation with basic density in comparison with pin penetration at a constant pressure. Nondestructive evaluation can be used in mass preselection of genetic materials, prior to subjecting them to a more accurate, reliable evaluation.
\end{abstract}

Key words: Resistography, Pilodyn ${ }^{\circledR}$, estimate.

\section{MODELAGEM DA DENSIDADE BÁSICA DA MADEIRA DE Eucalyptus grandis E Eucalyptus urophylla POR MÉTODOS NÃO DESTRUTIVOS}

\begin{abstract}
RESUMO: Objetivou-se, com este trabalho, avaliar a precisão da utilização de variáveis não destrutivas na inferência sobre a densidade básica das madeiras de Eucalyptus grandis e Eucalyptus urophylla. Foram utilizados 27 clones de Eucalyptus urophylla e 22 clones de Eucalyptus grandis oriundos de teste clonal implantado em Martinho Campos, Minas Gerais. Após a avaliação por técnicas não destrutivas de resistografia e penetração por um pino à pressão constante $\left(\right.$ Pilodyn $\left.^{\circledR}\right)$, os indivíduos foram abatidos e retirados discos a 2, 10, 30, 50 e $70 \%$ da altura comercial, além destes, foram extraídos também discos a 1,30 metros do solo. A densidade básica da madeira foi determinada pelo método de imersão em água. Os clones avaliados apresentaram valores em densidade básica variando de 0,412 a 0,609 g.cm $\mathrm{cm}^{-3}$ aos 42 meses e 0,408 a 0,664 g.cm $\mathrm{cm}^{-3}$ aos 54 meses. Os clones de Eucalyptus urophylla apresentaram densidade básica média superior em relação aos de Eucalyptus grandis. A variável amplitude apresentou melhor relação com a densidade básica comparada a penetração por um pino à pressão constante. A avaliação não destrutiva pode ser utilizada em uma pré-seleção massal de materiais genéticos, destinando-os posteriormente a uma avaliação mais precisa e confiável.
\end{abstract}

Palavras-chave: Resistografia, Pilodyn ${ }^{\circledast}$, estimativa.

\section{INTRODUCTION}

Wood is one of the most widely used natural resources, serving several purposes which include power generation (ACKOM et al., 2010; PALLARDY et al., 2003), pulp and paper production (GOMIDE et al., 2005), manufacture of engineered panels (HASELEIN et al., 2002; IWAKIRI et al., 2000), in addition to promoting environmental services such as immobilization of atmospheric carbon (ANDRADE et al., 2008). Its renewable nature is a significant advantage if compared with materials obtained from nonrenewable sources.

A major reflection of the large number of usable applications for wood is the increasing demand for the material. This, compounded by environmental problems resulting from the intense exploitation of this natural resource, has become a burden.

With the above in mind, search for alternative, sustainable sources of wood has intensified in recent decades, and research studies related to Eucalyptus are

${ }^{1}$ Forest Engineer, Ph.D. Candidate in Wood Science and Technology - Universidade Federal de Lavras/UFLA - Departamento de Ciências Florestais - Cx. P. 3037 - 37.200-000 - Lavras, MG, Brazil - allan_floresta@yahoo.com.br, vania_desa@yahoo.com.br ${ }^{2}$ Forest Engineer, Professor Ph.D. in Forest Sciences - Universidade Federal de Lavras/UFLA - Departamento de Ciências Florestais Cx. P. 3037 - 37.200-000 - Lavras, MG, Brazil - trugilho@ dcf.ufla.br

${ }^{3}$ Forest Engineer, M.Sc. Candidate in Wood Science and Technology- Universidade Federal de Lavras/UFLA - Departamento de Ciências Florestais - Cx. P. 3037 - 37.200-000 - Lavras, MG, Brazil - tmaffia@ hotmail.com

${ }^{4}$ Bachelor's Degree Candidate in Forest Engineering- Universidade Federal de Lavras/UFLA - Departamento de Ciências Florestais - Cx. P. 3037 - 37.200-000 - Lavras, MG, Brazil - depaulaprotasio@gmail.com 
showing that this genus can be a feasible alternative for the problem.

The genus Eucalyptus is well adapted to the climate conditions of Brazil and, being a fast-growing source of wood, has been massively used in all branches of the forest sector. However, productivity is not the only parameter determining whether or not a material is viable for a given purpose.

Use of wood to the best of its potential requires knowledge about its physical, anatomical, chemical and mechanical properties, and that causes studies to assess wood quality as feedstock to become lengthy, expensive processes. Depending on the end use, properties considered important for characterizing wood quality may vary, yet basic density is considered the main indicator of wood quality, as it correlates with all other wood properties, including retractability (WU et al., 2006; YAMASHITA et al., 2009), mechanical properties (NASCIMENTO et al., 1997) and anatomy (TOMAZELLO FILHO, 1987). Also, density affects all processes in which wood is present, including pulping (QUEIROZet al., 2004), charring (KHRISTOVA; KHALIFA, 1993), machining (Silva et al., 2007), log breakdown etc.

With that in mind, reducing the time and costs involved in characterizing wood quality, especially in connection with analysis of basic density, would be an interesting obstacle to overcome. Nondestructive methods or tests have great potential as analysis tools, since they are intended to qualify the material without jeopardizing its future use. In other words, here it is not necessary to fell trees in order toremove the material required for determination of basic density (CARRASCO; AZEVEDO, 2003).

Some devices have been developed and adapted that perform nondestructive evaluation of wood, including Resistograph ${ }^{\circledR}$ and Pilodyn ${ }^{\circledR}$. These devices were primarily designed to evaluate the soundness of wood pieces but, other than the original purpose, they have also been used as tools to make inferences about wood quality (CERALDI et al., 2001; KAHL et al., 2009; WU et al., 2010).

Basically, Pilodyn ${ }^{\circledR}$ consists of a hard pin that is spring-fired into wood at a constant pressure. Pin penetration should be negatively correlated with basic density, for the higher the density of the material the greater its resistance to pin penetration and, consequently, the shallower the depth reached by the Pilodyn ${ }^{\circledR}$ pin (GOUVÊA et al., 2011a, 2011b; NEVES et al., 2011; THIERSCH et al., 2006; VALE et al., 1995; WU et al., 2010).

Resistograph ${ }^{\circledR}$ is a device that probes a $3 \mathrm{~mm}$ micro drill with varying lengths into the wood piece, being automatically adapted to a drill speed mechanism (RINN et al., 1996). A reading device records a magnitude concerning drill difficulty in perforating the wood (amplitude), and the average amplitude is correlated with the density of the material.

Given these considerations, the objective of this study was to evaluate the efficiency of nondestructive analysis devices (Resistograph ${ }^{\circledR}$ and Pilodyn ${ }^{\circledR}$ ) in inferring wood density of clones from Eucalyptus grandis and Eucalyptus urophylla.

\section{MATERIAL AND METHODS}

\subsection{Biological material}

Wood samples were used from 49 clones of Eucalyptus urophylla and Eucalyptus grandis at ages 42 and 54 months, sourced from clonal experiments run by ArcelorMittal Bioenergia, located in the municipality of Martinho Campos, Minas Gerais. The study site is located at coordinates $19^{\circ} 19^{\prime}$ 'South and $45^{\circ} 14^{\prime}$ 'West, in a region with average annual temperature of $22^{\circ} \mathrm{C}$ and cumulative annual precipitation of $1,150 \mathrm{~mm}$. The clonal experiment area was subjected to subsoiling and base fertilization comprising $300 \mathrm{~kg} \cdot \mathrm{ha}^{-1}$ of Gafsa phosphate, followed by additional fertilization (top dressing) comprising $170 \mathrm{~kg} \cdot \mathrm{ha}^{-1}$ of NPK 6/30/6, $\mathrm{Zn}(1 \%), \mathrm{Cu}(0.7 \%)$ and $\mathrm{B}(1 \%)$.

The clones were selected based on mean annual increment, being evaluated both destructively and nondestructively. Five sample trees were used per genetic material, to a total of 245 trees. Table 1 itemizes the number of clones being analyzed.

Table 1 - Distribution of materials used in this study.

Tabela 1 - Distribuição do número de materiais utilizados neste estudo.

\begin{tabular}{lccc}
\hline \multirow{2}{*}{ Species } & \multicolumn{2}{c}{ Age (months) } & Total \\
\cline { 2 - 3 } & 42 & 54 & \\
\hline $\begin{array}{l}\text { Eucalyptus } \\
\text { urophylla S. T. Blake }\end{array}$ & 12 & 15 & 27 \\
$\begin{array}{l}\text { Eucalyptus } \\
\text { grandis W. Hill }\end{array}$ & 12 & 10 & 22 \\
\hline Total & 24 & 25 & 49 clones \\
\hline
\end{tabular}

\subsection{Nondestructive evaluation}

For each individual, readings were taken $1.30 \mathrm{~m}$ above ground level (DAP) using Pilodyn ${ }^{\circledR}$ and Resistograph ${ }^{\circledR}$. Four readings were taken with Pilodyn ${ }^{\circledR}$

Cerne, Lavras, v. 19, n. 1, p. 27-34, jan./mar. 2013 
while with Resistograph ${ }^{\circledR}$ only two readings were taken (Figure 1). This analysis was intended to obtain a more representative average value of nondestructive variables, noting that the Resistograph ${ }^{\circledR}$ drill perforates through the entire diameter of the stem while the Pilodyn ${ }^{\circledR}$ pin only penetrates a shallow depth into the stem.

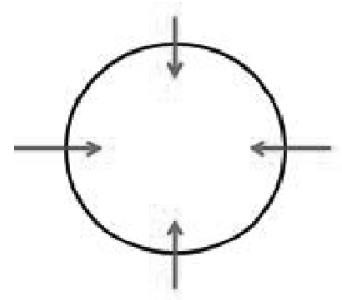

Pilodyn

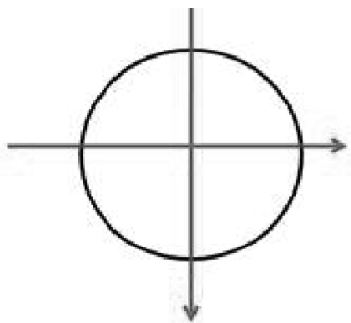

Resistograph
Planting row direction

Figure 1 - Graphic representation of nondestructive analysis devices.

Figura 1 - Esquema de aplicação dos equipamentos de avaliação não destrutiva.

\subsection{Longitudinal sampling}

Following nondestructive analysis, trees were felled and disks around $2.5 \mathrm{~cm}$ thick were removed from the $2 \%$, $10 \%, 30 \%, 50 \%$ and $70 \%$ portions of the merchantable height section (minimum diameter of $5 \mathrm{~cm}$ ) according to Downes et al. (1997), with an additional disk being removed from the section $1.30 \mathrm{~m}$ above ground level.

\subsection{Determination of basic density}

Two opposing wedges passing through the pith were removed from each disk. Determination of basic density is standardized by NBR 11941 (ASSOCIAÇÃO BRASILEIRA DE NORMAS TÉCNICAS - ABNT, 2003). Mean basic density was obtained using all longitudinal sampling points, except DAP.

\subsection{Statistical analysis}

Analysis of linear regression were run between nondestructive variables Resistograph ${ }^{\circledR}$ amplitude (AMP) and Pilodyn ${ }^{\circledR}$ penetration (PIL) and basic density of clones from same species and age, as well as indicative tests of residual homoscedasticity (Goldfeld-Quandt Test) and normality (Shapiro-Wilk Test).
Additionally, mean, maximum, minimum and coefficient of variation were determined for average basic density (DB MED), basic density $1.30 \mathrm{~m}$ above ground level (DB DAP), average amplitude recorded by Resistograph ${ }^{\circledR}$ (AMP) and Pilodyn ${ }^{\circledR}$ penetration (PIL) for each tree of Eucalyptus grandis and Eucalyptus urophylla at ages 42 and 54 months.

All statistical analysis were run using statistical software $\mathrm{R}$ version 2.9.2, and for regression analysis assumptions the lmtest package was used (HOTHORN et al., 2010).

\section{RESULTS AND DISCUSSION}

Table 2 provides mean, maximum, minimum values and coefficient of variation of average basic density (DB MED), basic density $1.30 \mathrm{~m}$ above ground level (DB DAP), average amplitude recorded by Resistograph ${ }^{\circledR}$ (AMP) and Pilodyn ${ }^{\circledR}$ pin penetration (PIL) for the Eucalyptus clones.

Density values found in this work were similar to results found by Brito et al. (1983) while working with Eucalyptus sp at age 120 months $\left(0.391\right.$ to $\left.0.593 \mathrm{~g} / \mathrm{cm}^{3}\right)$, indicating the great potential of the clones for charcoal production, the reason being that when higher density woods are charred, characteristics of the resulting charcoal such as apparent relative density (BRITO; BARRICHELLO, 1980), mechanical properties (BRITO et al., 1987) and energy density are all enhanced (BRAND, 2010).

The clones of Eucalyptus urophylla provided higher average values of basic density, comparatively with the clones of Eucalyptus grandis in both ages being considered. Therefore, the clones of Eucalyptus urophylla could be a good alternative in improvement programs aiming at increments in basic density. Higher values of average amplitude recorded by Resistograph ${ }^{\circledR}$ were also found for the clones of Eucalyptus urophylla, indicating a positive correlation between these variables.

As regards penetration by the Pilodyn ${ }^{\circledR}$ pin, average values found for clones of Eucalyptus grandis and Eucalyptus urophylla were close. The result indicates a low correlation between basic density and this nondestructive variable, since, numerically speaking, a significant difference was found between basic density values of the clones of Eucalyptus grandis and the clones of Eucalyptus urophylla.

Table 3 provides analysis of linear regression, residual standard deviation, Pearson linear correlation and tests of residual homoscedasticity and normality for the fitted models.

Cerne, Lavras, v. 19, n. 1, p. 27-34, jan./mar. 2013 
Table 2 - Mean, maximum, minimum values and coefficients of variation concerning DB MED, DB DAP, AMP and PIL for $E$. grandis and E. urophylla at ages 42 and 54 months.

Tabela 2 - Valores médios, máximos, mínimos e coeficientes de variação para DB MED, DB DAP, AMP e PIL para E. grandis e E. urophylla aos 42 e 54 meses.

\begin{tabular}{|c|c|c|c|c|c|c|}
\hline Age & Species & Characteristics & Mean & Maximum & Minimum & $\mathrm{CV}(\%)$ \\
\hline \multirow{8}{*}{ 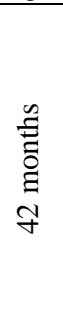 } & \multirow{4}{*}{ E. grandis } & $\operatorname{AMP}(\%)$ & 12.57 & 24.12 & 5.24 & 34.53 \\
\hline & & PIL (mm) & 10.75 & 14.50 & 7.00 & 17.22 \\
\hline & & DB MED $\left(\mathrm{g} \cdot \mathrm{cm}^{-3}\right)$ & 0.489 & 0.585 & 0.412 & 7.95 \\
\hline & & DB DAP $\left(\mathrm{g} \cdot \mathrm{cm}^{-3}\right)$ & 0.482 & 0.609 & 0.407 & 8.47 \\
\hline & \multirow{4}{*}{ E. urophylla } & $\operatorname{AMP}(\%)$ & 13.69 & 24.03 & 5.23 & 27.82 \\
\hline & & PIL (mm) & 10.95 & 15.00 & 8.00 & 13.59 \\
\hline & & DB MED $\left(\mathrm{g} . \mathrm{cm}^{-3}\right)$ & 0.541 & 0.616 & 0.458 & 5.73 \\
\hline & & DB DAP $\left(\mathrm{g} \cdot \mathrm{cm}^{-3}\right)$ & 0.520 & 0.604 & 0.429 & 7.65 \\
\hline \multirow{8}{*}{ 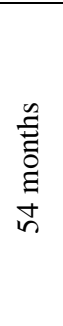 } & \multirow{4}{*}{ E. grandis } & $\operatorname{AMP}(\%)$ & 11.77 & 21.03 & 6.61 & 29.07 \\
\hline & & PIL (mm) & 12.32 & 15.38 & 9.25 & 13.03 \\
\hline & & DB MED $\left(\mathrm{g} \cdot \mathrm{cm}^{-3}\right)$ & 0.510 & 0.634 & 0.408 & 8.27 \\
\hline & & DB DAP $\left(\mathrm{g} \cdot \mathrm{cm}^{-3}\right)$ & 0.503 & 0.617 & 0.426 & 9.27 \\
\hline & \multirow{4}{*}{ E. urophylla } & $\operatorname{AMP}(\%)$ & 12.99 & 28.79 & 5.95 & 33.88 \\
\hline & & PIL (mm) & 12.18 & 15.25 & 8.00 & 13.88 \\
\hline & & DB MED $\left(\mathrm{g}^{-\mathrm{cm}^{-3}}\right)$ & 0.561 & 0.664 & 0.480 & 8.83 \\
\hline & & DB DAP $\left(\mathrm{g}^{\mathrm{c}} \mathrm{cm}^{-3}\right)$ & 0.540 & 0.649 & 0.454 & 9.48 \\
\hline
\end{tabular}

DB MED: average basic density; DB DAP: basic density at $1.30 \mathrm{~m}$; AMP: amplitude recorded by Resistograph ${ }^{\circledR}$; PIL: penetration depth of Pilodyn ${ }^{\circledR}$ pin; $\mathrm{CV}(\%)$ : coefficient of variation.

Table 3 - Analysis of linear regression of DB MED as a function of nondestructive variables (PIL and AMP) and DB DAP with DB MED. Statistics inherent in residuals generated by equations.

Tabela 3 - Análises de regressão linear da DB MED em função das variáveis não destrutivas (PIL e AMP) e DB DAP com DB MED. Estatísticas inerentes aos resíduos gerados pelas equações.

\begin{tabular}{|c|c|c|c|c|c|c|c|c|}
\hline \multirow{2}{*}{ Age } & \multirow{2}{*}{ Species } & \multirow{2}{*}{ Models } & \multicolumn{2}{|c|}{ Coefficients } & \multirow{2}{*}{$\mathrm{R}^{2}$} & \multicolumn{3}{|c|}{ Residuals } \\
\hline & & & $\beta_{0}$ & $\beta_{1}$ & & $\mathrm{~S}_{\mathrm{xy}}\left(\mathrm{g} \cdot \mathrm{cm}^{-3}\right)$ & $\mathrm{W}$ & GQ \\
\hline \multirow{6}{*}{ 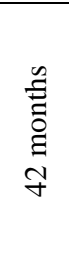 } & \multirow{3}{*}{ E. grandis } & 1. $\mathrm{DB} \mathrm{MED}=f(\mathrm{AMP})$ & $*$ & $*$ & $0.67 *$ & 0.021 & ns & ns \\
\hline & & 2. $\mathrm{DB} \mathrm{MED}=f(\mathrm{PIL})$ & $*$ & ns & $0.00^{\mathrm{ns}}$ & 0.038 & ns & $\mathrm{ns}$ \\
\hline & & 3. $\mathrm{DB} \mathrm{MED}=f(\mathrm{DB} \mathrm{DAP})$ & $*$ & $*$ & $0.74 *$ & 0.020 & $\mathrm{~ns}$ & $\mathrm{~ns}$ \\
\hline & \multirow{3}{*}{ E. urophylla } & 4. $\mathrm{DB} \mathrm{MED}=f(\mathrm{AMP})$ & $*$ & $*$ & $0.54^{*}$ & 0.018 & $\mathrm{~ns}$ & $\mathrm{~ns}$ \\
\hline & & 5. $\mathrm{DB} \mathrm{MED}=f(\mathrm{PIL})$ & $*$ & $*$ & $0.44 *$ & 0.027 & ns & ns \\
\hline & & 6. $\mathrm{DB} M E D=f(\mathrm{DB} \mathrm{DAP})$ & $*$ & $*$ & $0.76^{*}$ & 0.015 & ns & $\mathrm{ns}$ \\
\hline \multirow{6}{*}{$\begin{array}{l}\text { 吉 } \\
\tilde{\Xi} \\
\Xi \\
\dot{\Xi} \\
\text { in }\end{array}$} & \multirow{3}{*}{ E. grandis } & 7. $\mathrm{DB}$ MED $=f(\mathrm{AMP})$ & $*$ & $*$ & $0.54 *$ & 0.024 & ns & ns \\
\hline & & 8. $\mathrm{DB}$ MED $=f(\mathrm{PIL})$ & $*$ & $*$ & $0.39 *$ & 0.027 & ns & ns \\
\hline & & 9. $\mathrm{DB} M E D=f(\mathrm{DB} \mathrm{DAP})$ & $*$ & $*$ & $0.72 *$ & 0.020 & ns & ns \\
\hline & \multirow{3}{*}{ E. urophylla } & 10. $\mathrm{DB} \mathrm{MED}=f(\mathrm{AMP})$ & $*$ & $*$ & $0.62 *$ & 0.029 & ns & ns \\
\hline & & 11. $\mathrm{DB} \mathrm{MED}=f(\mathrm{PIL})$ & $*$ & $*$ & $0.32 *$ & 0.037 & ns & ns \\
\hline & & 12. $\mathrm{DB} \mathrm{MED}=f(\mathrm{DB} \mathrm{DAP})$ & $*$ & $*$ & $0.82 *$ & 0.020 & ns & ns \\
\hline
\end{tabular}

DB MED: average basic density; AMP: amplitude recorded by Resistograph ${ }^{\circledR}$; PIL: penetration depth by Pilodyn ${ }^{\circledR}$ pin, DB DAP: basic density at $1.30 \mathrm{~m} ; \beta$ : adjusted coefficients; $\mathrm{R}^{2}$ : adjusted coefficient of determination; $\mathrm{S}_{\mathrm{xy}}\left(\mathrm{g} . \mathrm{cm}^{-3}\right)$ : residual standard deviation; W: Shapiro-Wilk test of residual normality; GQ: Goldfeld-Quandt test of residual homoscedasticity; ns: nonsignificant at $95 \%$ confidence level; *: significant at $95 \%$ confidence level.

Cerne, Lavras, v. 19, n. 1, p. 27-34, jan./mar. 2013 
All fitted linear models (except Model 2) were significant. Residuals of significant linear models showed normality and homoscedasticity, thus meeting regression analysis assumptions.

It is worth noting that the coefficients of determination found for the fitted models ranged from moderate to low, in other words, the amplitude recorded by Resistograph ${ }^{\circledR}$ and the penetration depth by the Pilodyn ${ }^{\circledR}$ pin failed to considerably explain variability in basic density.

Therefore, in order to improve model quality, other variables can be added that are correlated with basic density but weakly correlated with nondestructive variables, such as DAP, dominant height and tree age (THIERSCH et al., 2006). Moreover, one can use multiple linear models introducing nondestructive variables as regression variables, or an interaction between them, to improve the $\mathrm{R}^{2}$ and the residual standard deviation.

The adjusted coefficients of determination for the equations having AMP as an independent variable were higher in comparison with the equations having PIL as a regression variable. This result is indicative of a better functional correlation of AMP with density, agreeing with results found by Gouvêa et al. (2011b).

The fact that AMP and basic density were moderately correlated confers greater prediction accuracy to the fitted models if compared with the obtained functions between basic density and pin penetration (PIL). This assertion is supported by checking the lower values of residual standard deviation referring to the models using AMP to predict DB MED. The higher correlation between DB MED and AMP is due to the fact that resistography assesses the entire diametral portion of a tree, whereas Pilodyn ${ }^{\circledR}$ only assesses portions closer to the vascular cambium, thus providing a less representative sample of the stem.

Kahl et al. (2009), when evaluating prediction efficiency for wood density in individuals of the genus Abies using resistography (AMP), found that $65 \%$ of variation in DB MED was explained by variation in AMP $\left(\mathrm{R}^{2}=0.65\right)$. Ceraldi et al. (2001) fitted models between DB MED and AMP when evaluating the correlation between mechanical and physical properties of old wooden structures using resistography, and found coefficients of determination of 0.66 and 0.59 for the linear and potential models respectively.

Wu et al. (2010) analyzed the correlation between pin penetration $\left(\operatorname{Pilodyn}^{\circledR}\right)$ and the physico-mechanical properties of wood from Eucalyptus clones at 56 months and found coefficients of determination ranging from 0.35 to 0.41 for predictive models of DB MED with PIL, these being close and similar to values found in this work. Vale et al. (1995) analyzed the correlation of Pilodyn ${ }^{\circledR}$ pin penetration with average basic density of Eucalyptus grandis at age 8 years and found a correlation coefficient of -0.55. Neves et al. (2011) found a linear correlation coefficient of -0.80 between Pilodyn ${ }^{\circledR}$ pin penetration and average basic density for Eucalyptus clones at different planting sites.

Generally speaking, a strong correlation exists between basic density $1.30 \mathrm{~m}$ above ground level (DAP) and the average basic density of a tree individual, which is a valuable piece of information in that it could facilitate laboratory assessment of woods and, as a result, reduce costs and time involved in determination of basic density. The best model fit between average basic density and basic density at DAP level was found for the clones of Eucalyptus urophylla at 54 months. This result is an indication that it is possible to estimate the average basic density of a tree from a sample taken at DAP level.

Similar results were found by Brasil and Ferreira (1979) and Vital et al. (1981), who worked with Eucalyptus grandis wood. These authors argued that it is possible to estimate average basic density based on samples taken at DAP height level. Sturion et al. (1987), when working with several species of the genus Eucalyptus, argued that more accurate estimates can be obtained by using the relative density at the $25 \%$ portion (for E. camaldulensis, E. maculata, E. propinqua and E. tereticornis), at the $50 \%$ portion (for E. cloeziana, E. urophylla and E. grandis) and at the $75 \%$ portion of the merchantable height section (for E. pilularis).

Figure 2 provides fitted models for DB MED with nondestructive variables and DB DAP.

An increasing tendency was noted for AMP with the increase in DB MED, as the higher the wood density the greater its resistance to drill perforation and the greater the AMP recorded by Resistograph ${ }^{\circledR}$, supporting results found by Gouvêa et al. (2011a, 2011b). The opposite occurs with PIL, as the higher the wood density the greater its resistance to pin penetration, this variable correlating negatively with average basic density, as was observed by Vale et al. (1995) and Wu et al. (2010).

Cerne, Lavras, v. 19, n. 1, p. 27-34, jan./mar. 2013 


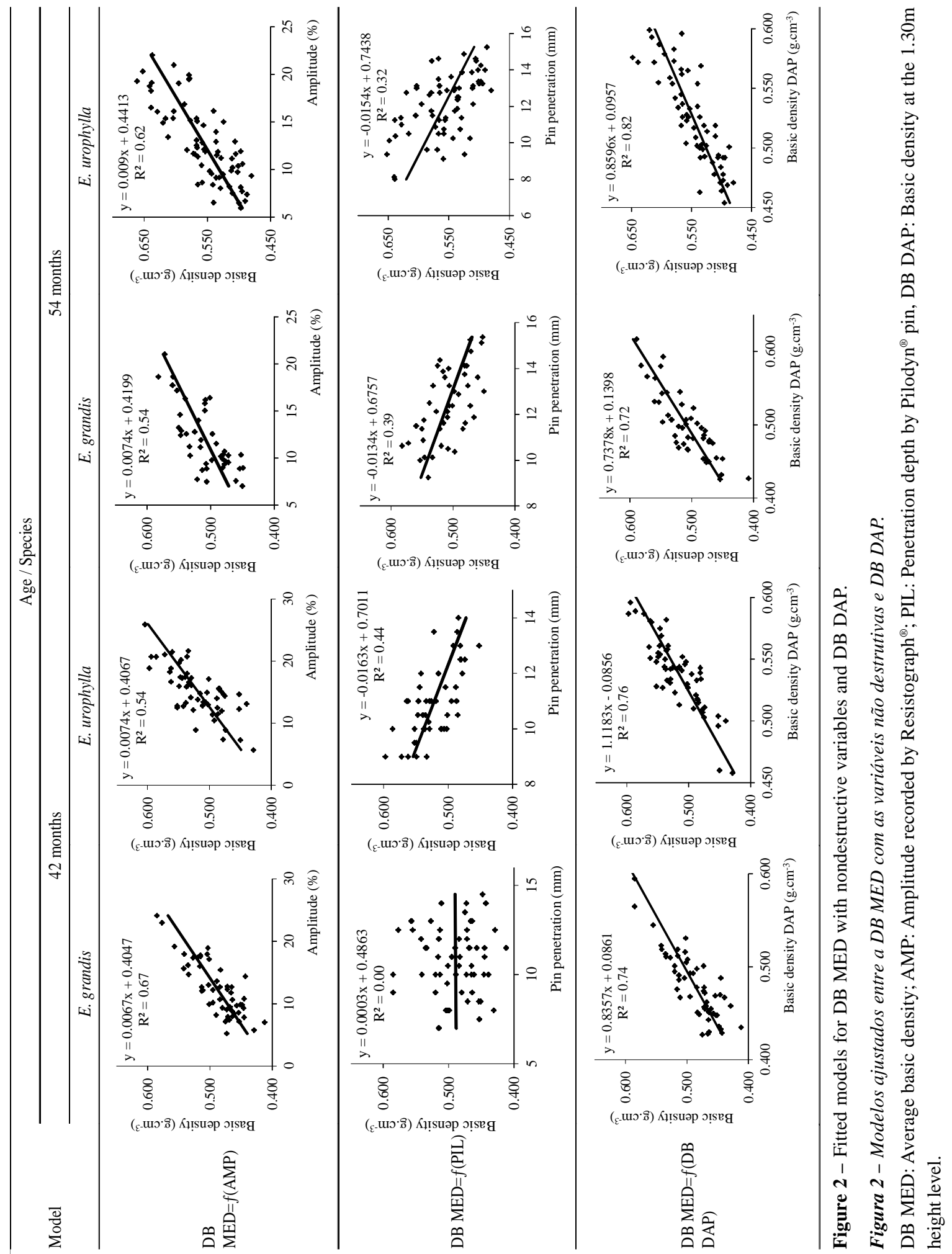

Cerne, Lavras, v. 19, n. 1, p. 27-34, jan./mar. 2013 


\section{CONCLUSIONS}

The correlations between basic density and nondestructive variables AMP (resistography) and PIL (pin penetration at a constant pressure) were moderate and low respectively.

The fitted linear models correlating amplitude recorded by the Resitograph ${ }^{\circledR}$ device provided greater accuracy in comparison with the models using pin penetration at a constant pressure.

Use of nondestructive evaluation devices is suggested for a preliminary selection of clones of Eucalyptus grandis and Eucalyptus urophylla, prior to subjecting them to a more accurate evaluation.

The fitted models that used the regression variable 'amplitude' can be used for predicting average basic density, provided the estimation does not require high precision.

\section{ACKNOWLEDGEMENTS}

The authors wish to thank CNPq, FAPEMIG and Capes for providing financial support, and ArcelorMittal Bioenergia for donating the biological material used in this study.

\section{REFERÊNCIAS}

ACKOM, E. K.; MABEE, W. E.; SADDLER, J. N. Industrial sustainability of competing wood energy options in Canada. Applied Biochemistry and Biotechnology, Clifton, v. 162, p. 2259-2272, 2010.

ANDRADE, H. J.; BROOK, R.; IBRAHIM, M. Growth, production and carbon sequestration of silvopastoral systems with native timber species in the dry lowlands of Costa Rica. Plant and Soil, The Hague, v. 308, n. 1/2, p. 11-22, 2008.

\section{ASSOCIAÇÃO BRASILEIRA DE NORMAS TÉCNICAS.}

NBR 11941: madeira: determinação da densidade básica. Rio de Janeiro, 2003. 6 p.

BRAND, M. A. Energia de biomassa florestal. Rio de Janeiro: Interciência, 2010. 114 p.

BRASIL, M. A. M.; FERREIRA, M. Características das fibras de madeira de Eucalyptus grandis, aos anos de idade. IPEF, Piracicaba, n. 19, p. 80-97, 1979.

BRITO, J. O.; BARRICHELO, L. E. G. Correlações entre características físicas e químicas da madeira e a produção de carvão: 2., densidade da madeira x densidade do carvão. IPEF, Piracicaba, n. 20, p. 101-113, jun. 1980.

BRITO, J. O.; BARRICHELO, L. E. G.; SEIXAS, F. Análise da produção energética e de carvão vegetal de espécies de eucalipto. IPEF, Piracicaba, n. 23, p. 53-56, 1983.

BRITO, J. O.; TOMAZELLO FILHO, M.; SALGADO, A. L B. Produção e caracterização do carvão vegetal de espécies e variedades de bambu. IPEF, Piracicaba, n. 36, p. 13-17, 1987.

CARRASCO, E. V. M.; AZEVEDO, A. P. Avaliação não destrutiva de propriedades mecânicas de madeiras através de ultra-som: fundamentos físicos e resultados experimentais. Cerne, Lavras, v. 9, n. 2, p. 178-191, 2003.

CERALDI, C.; MORMONE, V.; ERMOLLI, E. R. Resistographic inspection of ancient timber structures for the evaluation of mechanical characteristics. Materials and Structures, New York, v. 34, n. 1, p. 59-64, 2001.

DOWNES, G. M.; HUDSON, I. L.; RAYMOND, C. A.; DEAN, G. H.; MICHELL, A. J.; SCHIMLECK, R.; EVANS, R.; MUNERI, A. Sampling plantation eucalypts for wood and fibre properties. Collingwood: CSIRO, 1997. 144 p.

GOMIDE, J. L.; COLODETTE, J. L.; OLIVEIRA, R. C. O.; SILVA, C. M. Caracterização tecnológica, para produção de celulose, da nova geração de clones de Eucalyptus do Brasil. Revista Árvore, Viçosa, v. 29, n. 1, p. 129-137, jan./fev. 2005.

GOUVÊA, A. F. G.; TRUGILHO, P. F.; COLODETTE, J. L.; BIANCHI, M. L.; SORAGI, L. C.; OLIVEIRA, A. C. Relação entre características da madeira da polpa celulósica de Eucalyptus com métodos não destrutivos na árvore viva. Scientia Forestalis, Piracicaba, v. 39, n. 90, p. 205-220, 2011a.

GOUVÊA, A. F. G.; TRUGILHO, P. F.; GOMIDE, J. L.; SILVA, J. R. M.; ANDRADE, C. R.; ALVES, I. C. N. Determinação da densidade básica da madeira de Eucalyptus por diferentes métodos não destrutivos. Revista Árvore, Viçosa, v. 3, n. 2, p. 349-358, fev. 2011b.

HASELEIN, C. R.; CALEGARI, L.; BARROS, M. V.; HACK, C.; HILLIG, E.; PAULESKI, D. T.; POZZERA, F. Resistência mecânica e à umidade de painéis aglomerados com partículas de madeira de diferentes dimensões. Ciência Florestal, Santa Maria, v. 12, n. 2, p. 127-134, 2002. 
HOTHORN, T.; ZEILEIS, A.; MILLO, G.; MITCHELL, D. Testing linear regression models: $\mathrm{R}$ package version 2.11.1. Disponível em: 〈http://r-forge.r-project.org〉. Acesso em: 24 nov. 2010.

IWAKIRI, S.; CUNHA, A. B.; ALBUQUERQUE, C. E. C.; GORNIAK, E.; MENDES, L. M. Resíduos de serrarias na produção de painéis de madeira aglomerada de eucalipto. Scientia Agraria, Curitiba, v. 1, n. 1/2, p. 23-28, 2000.

KAHL, T.; WIRTH, C.; MUND, M.; BOHNISCH, G.; SCHULZE, E. D. Using drill resistance to quantify the density in coarse woody debris of Norway spruce. European Journal of Forestry Research, London, v. 128, p. 467-473, 2009.

KHRISTOVA, P.; KHALIFA, A. W. Carbonization of some fast-growing species in Sudan. Applied Energy, London, v. 45, p. 347-354, 1993.

NASCIMENTO, C. C.; GARCIA, J. N.; DIÁZ, M. P. Agrupamento de espécies madeireiras da Amazônia em função da densidade básica e propriedades mecânicas. Madera y Bosques, Xalapa, v. 3, n. 1, p. 33-52, 1997.

NEVES, T. A.; PROTÁSIO, T. P.; COUTO, A. M.; TRUGILHO, P. F.; SILVA, V. O.; VIEIRA, C. M. M. Avaliação de clones de Eucalyptus em diferentes locais visando à produção de carvão vegetal. Pesquisa Florestal Brasileira, Colombo, v. 31, n. 68, p. 319-330, 2011.

PALLARDY, S. G.; GIBBINS, D. E.; RHOADS, J. L. Biomass production by two-year-old poplar clones on floodplain sites in the Lower Midwest, USA. Agroforestry Systems, Heidelberg, v. 59, p. 21-26, 2003.

QUEIROZ, S. C. S.; GOMIDE, J. L.; COLODETTE, J. L.; OLIVEIRA, R. C. Influência da densidade básica da madeira na qualidade da polpa kraft de clones hibrídos de Eucalyptus grandis w. Hill ex Maiden x Eucalyptus urophylla s. T. Blake. Revista Árvore, Viçosa, v. 28, n. 6, p. 901-909, 2004.

RINN, F.; SCHWEINGRUBER, F. H.; SCHAR, E.

Resistograph and X-ray density charts of wood comparative evaluation of drill resistance profiles and X-ray density charts of different wood species. Holzforschung, Berlin, v. 50, n. 4, p. 303-311, 1996.
SILVA, J. R. M.; LIMA, J. T.; TRUGILHO, P. F. Usinabilidade da madeira de Eucalyptus grandis em diferentes regiões da medula a casca. Cerne, Lavras, v. 13, n. 1, p. 25-31, 2007.

STURION, J. A.; ALBINO, J. C.; MORITA, M.; PEREIRA, J. C. D. Variação da densidade básica da madeira de doze espécies de Eucalyptus plantadas em Uberaba, MG. Boletim de Pesquisa Florestal, Colombo, n. 14, p. 28-38, 1987.

THIERSCH, C. R.; SCOLFORO, J. R.; OLIVEIRA, A. D.; REZENDE, G. D. S. P.; MAESTRI, R. O uso de modelos matemáticos na estimativa da densidade básica da madeira em plantios de clones de Eucalyptus sp. Cerne, Lavras, v. 12, n. 3, p. 264-278, 2006.

TOMAZELLO FILHO, M. Variação radial da densidade básica em estrutura anatômica da madeira do Eucalyptus globulus, E. pellita e E. acmenioides. IPEF, Piracicaba, n. 36, p. 35-42, 1987.

VALE, A. T.; MOURA, V. P. G.; MARTINS, I. S. Densidade básica média em função da produtividade de penetração do pino do Pilodyn" e da classe diamétrica e variação axial da densidade básica em Eucalyptus grandis Hill ex Maiden. Revista Árvore, Viçosa, v. 19, p. 80-91, 1995.

VITAL, B. R.; PEREIRA, A. R.; DELLA LUCIA, R. M. Influência do espaçamento na qualidade da madeira de Eucalyptus grandis, aos 30 meses de idade. Revista Árvore, Viçosa, v. 2, n. 5, p. 210-217, 1981.

WU, S.; XU, J.; LI, G.; RISTO, V.; LU, Z.; LI, B.; WANG, W. Use of the pilodyn for assessing wood properties in standing trees of Eucalyptus clones. Journal of Forestry Research, London, v. 21, n. 1, p. 68-72, 2010.

WU, Y. Q.; KAZUO, H.; LIU, Y.; CAI, Y.; SUGIMORI, M. Relationships of anatomical characteristics versus shrinkage and collapse properties in plantation-grown eucalypt wood from China. Journal of Wood Science, London, v. 52, n. 3, p. 187-194, 2006.

YAMASHITA, K.; HIRAKAWA, H.; NAKATANI, H.; IKEDA, M. Tangential and radial shrinkage variation within trees in sugi (Cryptomeria japonica) cultivars. Journal of Wood Science, London, v. 55, n. 3, p. 161-168, 2009. 